\title{
Music Education for Some: Music Standards at the Nexus of Neoliberal Reforms and Neoconservative Values
}

\author{
Jess Mullen \\ University of Wisconsin, Madison (USA)
}

Educational standards movements have manifested in the widespread adoption of statewide educational standards in mathematics and literacy in the United States. Within this policy context, the National Coalition for Core Arts Standards published educational standards for four fine arts disciplines, including music. Drawing from critical theory, this essay understands the National Core Arts Standards in Music as a product of a hegemonic alliance between neoliberal and neoconservative interests that run counter to the National Association for Music Education's mission of "promoting the understanding and making of music by all." By linking music education to workplace skills, establishing uniform benchmarks to improve educational efficiency, and codifying long held Eurocentric epistemologies of musical value, the National Core Arts Standards in Music stand to exacerbate existing inequities in music classrooms. As an alternative to the contemporary common sense of schooling, the possibilities and challenges of a democratic music education for creating counterhegemonic spaces are explored.

Keywords: music education policy, standards, inequity, democratic music education

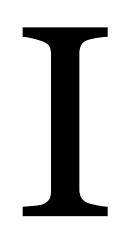

approach the topic of neoliberal education reforms and neoconservative values from the perspective of a current teacher educator and a former high school music teacher in a large Midwestern city in the United States. As a high school teacher, I experienced first-hand the day-to-day effects of datadriven instruction and teacher surveillance that embody neoliberal reforms. Because the school where I taught frequently fell short on state and district mandated assessments, all teachers were required to employ so-called researched-based literacy strategies and issue standardized tests resembling the ACT (American College Test)-one of the two prominent assessments for college admittance in the United States-every five weeks. Despite these mandates, I did manage to find

(C) Jess Mullen. The content of this article is the sole responsibility of the author. The ACT Journal and the Mayday Group are not liable for any legal actions that may arise involving the article's content, including, but not limited to, copyright infringement. 
small cracks for resisting neoliberal reforms, most notably in my band room, where my students and I went on an adventurous journey in collaboration by creating our own arrangements of beginning band staples as well as pop and hip-hop songs. As a teacher educator, I constantly deal with the tension between providing my preservice teachers with a democratic vision of music education that opens possibilities for student creativity and agency, and with adequately preparing them for the realities of teaching in today's public schools, which embody an increasingly narrow vision of education tied to standards and measurable outcomes. This essay critiques the increasing standardization of music learning as part of neoliberal and neoconservative agendas, and demonstrates how these reforms contribute to, rather than ameliorate, inequity in music classrooms.

In the United States and elsewhere, contemporary education policy has been driven by neoliberal notions of standardization, narrow measures of accountability, and market-driven competition (Apple 2006, Horsley 2009). Educational standards movements, a key component of neoliberal accountability regimes, have manifested in the widespread adoption of Common Core State Standards (CCSS) in mathematics and literacy in the United States. The CCSS initiative began in 2007, with the initial development of common standards at the CCSS annual policy forum. Presently, forty-one states and the District of Columbia have adopted CCSS.

Within this policy context, in 2014, the National Coalition for Core Arts Standards (NCCAS) published educational standards for four fine arts disciplines, including music. The National Association for Music Education (NAfME), the largest professional organization for music educators in the United States, was instrumental in developing the National Core Arts Standards in Music and promoting their adoption. The National Core Arts Standards are informed by international arts standards and are aligned with the CCSS in mathematics and literacy. Advocates for the new standards claim that they reflect authentic artistic processes or artistic literacy in music and will contribute to career and college-ready competencies necessary in the 21st century (Shuler, Norgaad and Blakeslee 2014).

Supporters see the National Core Arts Standards as a potential solution to inequities in arts education in the United States. According to the Arts Education in Public Elementary and Secondary Schools 1999-2000 and 2009-10 reports, despite "robust infrastructure of arts education in American schools" (National Coalition for Core Arts Standards 2016, 3) there exist “extreme inequities in students' access to arts education, indicating that arts education is not universally available,

Mullen, Jess. 2019. Music education for some: Music standards at the nexus of neoliberal reforms and neoconservative values. Action, Criticism, and Theory for Music Education 18 (1): 44-67. doi:10.22176/act18.1.44 
is too often limited to music and art, and is inconsistent across grade levels" (3). An underlying assumption of the National Core Arts Standards suggests that by providing teachers with sequential learning standards, they will improve arts instruction for all students.

Often, music education must defend its place in school curricula, especially during times of educational reform. Establishing curricular standards has long been part of a strategy to legitimize music as a core subject of study in public schools (Benedict 2006, Koza 2010, Mark 1995). Notably, in 1994 NAfME (then the Music Educators National Conference) successfully lobbied for the inclusion of music as a core subject as part of Goals 200o: Educate America, a congressional act that first established national standards for school subjects (Mark 2002). Although creating educational standards in music is not a new phenomenon, the National Core Arts Standards in Music represent an ideological compromise that aligns music education to neoliberal and neoconservative interests.

In Educating the "Right" Way, Michael Apple (2006) discusses how seemingly disparate groups on the political right make creative alliances to reshape education policy and curriculum. Apple (2006) argues that the success of conservative reforms is the result of compromises between ideological blocs that shape the public's fundamental understanding of schooling.

One of the most important objects of the rightist agendas is changing our common sense, altering the meanings of the most basic categories, the keywords we employ to understand the social and educational world and our place in it. In many ways, a core aspect of these agendas is about what has been called identity politics. The task is to radically alter who we think we are and how our major institutions are to respond to this changed identity. (8)

The reformulation of key terms and how we think about public institutions has serious consequences for schooling. Ideas such as freedom have been reduced to consumer choice; democracy is narrowly framed in terms of electoral politics, choosing one candidate over the other to represent one's interests; and equality is imagined as everyone having the same choices. In education, this understanding of freedom, democracy, and equality has manifested in school choice through charter schools and state-sponsored voucher programs. The underlying logic of such programs is that choice and the invisible hand of the market will drive competition, thereby ensuring better schools for everyone. The creation of educational markets has effectively transformed schooling into a commodity, something one shops for, no different than a cell phone or new shoes. The commodification of schooling begs

Mullen, Jess. 2019. Music education for some: Music standards at the nexus of neoliberal reforms and neoconservative values. Action, Criticism, and Theory for Music Education 18 (1): 44-67. doi:10.22176/act18.1.44 
the question: what is music education selling? In other words, how has music education reformulated its identity to adapt to the neoliberal common sense of schooling?

The National Core Arts Standards in Music are key to understanding the effects of contemporary educational ideologies on the identity and values of music education in the United States. The National Core Arts Standards in Music align music education with neoliberal ideologies by linking music education to workplace skills, thus creating human capital for a globalized economy, and by establishing uniform benchmarks to improve educational efficiency. This reimagining of music education contributes to managerial notions of schooling that produce new markets for curricular materials and assessments needed to implement the new standards. Moreover, the National Core Arts Standards in Music codify long held Eurocentric epistemologies of musical value, thus satisfying neoconservatives' desire to preserve so-called real knowledge in an increasingly globalized world. Although these reforms are ostensibly undergirded by notions of equality or sameness, by adapting music education to dominant educational ideologies, the National Core Arts Standards in Music exacerbate existing inequities in music classrooms, thus making NAfME's promise of "music education for all" further out of reach. Rather than capitulate to neoliberal and neoconservative visions of schooling, democratic modes of music education hold promise for creating more equitable music classrooms. A democratic music education is messy and deeply local and can act as a counterhegemonic space that challenges prevailing notions of standardization, meritocracy, and competition encouraged under neoliberal reforms.

\section{Remaking Music Education for a Globalized Economy}

Neoliberalism, arguably the strongest ideological current in contemporary educational reform, emphasizes the rights of individuals to compete in the free market (Apple 2006, Ball 2012, Horsley 2015). Characterized by the often-contradictory principles of a weak state, consumer choice and markets, the rise of neoliberalism affects both material and social relations through the "economization of social life and the creation of new opportunities for profit" (Ball 2012, 3). Neoliberalism has shaped how citizens think about institutions and the public good, opening opportunities for private profit in the public sector.

Neoliberal reforms in education have redefined both the purpose and process of schooling to satisfy the labor demands of multinational corporations:

Mullen, Jess. 2019. Music education for some: Music standards at the nexus of neoliberal reforms and neoconservative values. Action, Criticism, and Theory for Music Education 18 (1): 44-67. doi:10.22176/act18.1.44 
Recent reforms frame education as a vehicle for creating human capital capable of competing in a global workforce in which transnational corporations can choose where to locate. To compete in the global market schools must be efficient and produce maximum output (i.e., student achievement) while minimizing input (i.e., resources). (Horsley 2009, 6)

Under neoliberalism, education is an integral component for meeting the needs of global capitalism through the production of human capital; therefore, school curricula must be tied to future economic labor demands. Neoliberal educational initiatives claim that prescribed academic standards ensure that students are prepared for entry-level careers, college entrance, or work training programs by developing critical thinking, problem-solving, and analytical skills, among others. Although problem-solving and critical thinking have been desired educational goals prior to neoliberal educational reforms, the contemporary framing of these terms is important. Under neoliberal ideology, standards that dictate curricula and assessments are only valuable insomuch as they contribute to the advancement of global economic activity.

Teaching 21st-century skills-a nebulous constellation of assumed competencies necessary to succeed in a globalized economy-has been the rallying cry for a growing number of business leaders, politicians, and educators (Rotherham and Willingham 2009). One of the most prolific advocates of 21st-century skills is the Partnership for 21st Century Learning. Founded in 2002, the Partnership for 21st Century Learning is a "coalition bringing together the business community, education leaders, and policymakers to position 21st-century readiness at the center of US k-12 education..." (Partnership for 21st Century Learning n.d., para. 1). ${ }^{1}$ The aim of this organization is to promote their framework for 21st-century skills in schools and educational policy. The founding organizations include AOL Time Warner Foundation, Apple Computers, Cable in the Classroom, Cisco Systems, Dell Computer Corporation, Microsoft Corporation, National Education Association, and SAP Software Solutions.

The Partnership for 21st Century Learning identifies four 21st century outcomes: (a) content knowledge; (b) learning and innovation skills; (c) information, media and technology skills; and (d) life and career skills. The first category of outcomes, content knowledge, contains familiar school subjects including language arts, mathematics, history, and the arts; however, the next three categories specifically link schooling to future workplace skills.

Mullen, Jess. 2019. Music education for some: Music standards at the nexus of neoliberal reforms and neoconservative values. Action, Criticism, and Theory for Music Education 18 (1): 44-67. doi:10.22176/act18.1.44 
Learning and innovation skills increasingly are being recognized as the skills that separate students who are prepared for increasingly complex life and work environments in the 21st century, and those who are not. A focus on creativity, critical thinking, communication, and collaboration is essential to prepare students for the future. (Partnership for 21st Century Learning 2015, 3)

Creativity, critical thinking, communication, and collaboration are familiar terms for educators; nevertheless, the framing of these outcomes as 21st-century skills links these terms to the future demands of the workplace. Differing from strictly vocational education, discourses surrounding 21st-century skills connect various domains of learning to a student's economic and civic success in a technologyladen future, casting education as a site for producing human capital for the global economy.

To assert the utility of music education in public schools, the National Core Arts Standards in Music link music education to the creation of human capital by suggesting that music study contributes to 21st-century skills. Shuler, Norgaard, and Blakeslee (2014) explain how the current education policy context shaped the National Core Arts Standards in Music, compared to the 1994 Standards:

The current environment differs from 1994 in a number of respects, ranging from the greater availability of technology to an increased emphasis on assessment and college readiness...By embracing and applying the new standards, music teachers will also cultivate the cross-cutting college- and career-ready and 21st-century skills that are increasingly expected of students in all subject areas. (41)

Advocates for the National Core Arts Standards link music study to the development of 21st-century skills to prepare students for future work. The Partnership for 21st Century Learning also provides a skills map ${ }^{2}$ to demonstrate how arts education supports the development of 21st-century skills. Along with creativity and collaboration, the Partnership's document includes innovation, productivity, accountability, and leadership and responsibility as 21st-century skills, thus linking traditional outcomes in arts education to other workplace competencies. By connecting music education to 21st-century skills, the National Core Arts Standards in Music answer neoliberal demands for human capital and reframe the value of music education in the service of global capitalism.

\section{Educational Efficiency}

In a time of neoliberal reform, schools must not only produce human capital, they must also operate according to reductive economic notions of efficiency. The

Mullen, Jess. 2019. Music education for some: Music standards at the nexus of neoliberal reforms and neoconservative values. Action, Criticism, and Theory for Music Education 18 (1): 44-67.

doi:10.22176/act18.1.44 
central assumption of neoliberal policies is that competition and consumer choice compel schools to improve their effectiveness and efficiency through market forces.

Neoliberal theory claims that the ensuing competition for the best output drives the education system to constantly improve in efficiency and results. Curriculum development thus lies in the purview of a centralized government either at the national or regional level. The central government issues a standardized curriculum, a set of national standards for all students, or both. (Horsley 2009, 6)

Advocates for neoliberal reforms suggest that market-based competition will improve educational outputs, namely test scores. Neoliberal policies operate under a survival-of-the-fittest mentality, according to which the best schools will prosper, and so-called underperforming schools will eventually close due to market forces. In order for schools to compete, however, they must be assessed by uniform measures, making educational standards and benchmarks a necessary component for constructing neoliberal accountability regimes that encourage market-based competition.

Authorized in 2002, President George W. Bush's signature legislation, No Child Left Behind (NCLB), formally enacted neoliberal educational policies at a national level in the United States. NCLB established high-stakes testing as a means to hold teachers and schools accountable for student achievement and to provide families with objective quality indicators of a school's performance (Hursh 2007). Following the logic of NCLB, families could effectively shop for the best quality schools for their children, and so-called underperforming schools would be spurred to improve. NCLB relied on test scores to measure Adequate Yearly Progress (AYP), which was tied to federal funds. Schools that did not make AYP according to state-mandated benchmarks faced sanctions and possible closure (Hursh 2007).

In 2009, President Barack Obama's reformulation of NCLB, known as Race To The Top (RTTT), responded to critiques that NCLB was overly punitive. Nonetheless, RTTT continued to operate on neoliberal ideas of competition and accountability. Rather than issuing sanctions to underperforming schools, RTTT created a competitive grant program that rewarded states for implementing educational policies in four areas: (a) adopting standards and assessments; (b) building data systems to measure student growth and inform improvements in instruction; (c) recruiting effective teachers in high need areas and; (d) turning around low-

Mullen, Jess. 2019. Music education for some: Music standards at the nexus of neoliberal reforms and neoconservative values. Action, Criticism, and Theory for Music Education 18 (1): 44-67. doi:10.22176/act18.1.44 
achieving schools (U.S. Department of Education n.d., para. 1). Adopting statewide standards is at the heart of these reforms, a necessary component for creating data systems and measuring teacher effectiveness. Although RTTT did not prescribe curricular standards, many states adopted Common Core State Standards in response to the legislation. Despite RTTT's less punitive approach, its central premise remains the same: teacher effectiveness and student performance as measured by high-stakes testing will improve through competition and accountability.

Contemporary educational reforms further incentivized creating statewide educational standards. In response to the absence of music standards in Goals 2000: Educate America Act, NAfME assembled a massive lobbying effort to be among the first fine and performing arts disciplines to establish national standards (Mark 1995). The adoption of the national standards for music and the passing of Goals 2000: Educate America Act in 1994, which identified music education as a core subject, were celebrated as victories by music educators and scholars alike (Koza 2010, Mark 1995). Despite this legislative success, the codification of music as a core subject has yet to raise the status of music education to that of tested subjects, such as mathematics and literacy (Benedict 2006, Horsley 2009, Koza 2010).

Standards alone do not necessarily increase educational efficiency, but they are an essential component for constructing and legitimizing neoliberal accountability regimes. One example, encouraged under President Obama's grant program RTTT, is teacher effectiveness systems. In my home state of Wisconsin, the Department of Public Instruction developed an Educator Effectiveness System based on the Danielson Framework, a popular teacher evaluation system developed by former economist and current educational policy consultant Charlotte Danielson. Establishing student learning outcomes that are connected to academic standards is central to the Educator Effectiveness System. Teachers are then assessed based on the data collected during an evaluation cycle that demonstrates evidence that students have achieved selected outcomes. Educator evaluation systems require uniform benchmarks to measure and track student progress and to evaluate teachers. The National Core Arts Standards provide these benchmarks, which legitimize standards-aligned curricula and reduce the complexity and richness of music teaching and learning to rubric-based assessments that can be easily quantified for analysis. Therefore, districts are able to claim that these assessments, which are increasingly provided by private for-profit corporations, are valid indicators of student achievement and teacher effectiveness.

Mullen, Jess. 2019. Music education for some: Music standards at the nexus of neoliberal reforms and neoconservative values. Action, Criticism, and Theory for Music Education 18 (1): 44-67. doi:10.22176/act18.1.44 
Teacher effectiveness systems contribute to what Ball (2003) refers to as performativity, or "a technology, a culture, and a mode of regulation that employs judgments, comparisons and displays as means of incentive, control, attrition, and change-based on rewards and sanctions" (216). Performativity aligns teacher identities to neoliberal values, emphasizing educational efficiency, competition, and meeting prescribed targets or benchmarks. This is not only a shift in teacher identity but a shift in ethics: "the ethics of competition and performance are very different from the older ethics of professional judgment and co-operation" (Ball 2003, 220). Thus, the good teacher is one who gets results and meets or exceeds targets, rather than one who acts on professional judgment or builds relationships.

Competition and performance have long been a part of music education in the United States, especially among secondary performing ensembles. It could be argued that ensemble directors have always experienced a certain level of performativity, as the nature of their work is often on display through concerts and adjudicated performances. The kind of performativity teachers experience under neoliberal reforms, however, is qualitatively different from traditional models of performance assessment in music. Under neoliberalism, performance is measured by atomistic assessments of individual students that are tied to prescribed educational standards. This kind of accountability, driven by data and added-value measures, differs from traditional assessment wherein ensembles are evaluated as a whole, often through group performance based on the professional judgments of music educators. This is not to say that previous models of assessment in music education are not problematic in their own right, but to make a distinction between neoliberal notions of accountability and previous models in music education.

\section{New Managerialism: Neoliberal Reforms and Teachers' Work}

In The Managerial School, Sharon Gewirtz (2002) demonstrated how neoliberal education reforms changed the way school administrators in the United Kingdom viewed their role in the school community and the ethics that guided their leadership. In the United States, competitive markets and school choice have manifested in the expansion of charter schools and voucher systems that divert public dollars to private interests. The logic underlying the expansion of school choice programs suggests that competition for students among schools will lead to an overall improvement in the educational system, especially for marginalized students trapped in so-called failing public schools. However, as students and families shop for

Mullen, Jess. 2019. Music education for some: Music standards at the nexus of neoliberal reforms and neoconservative values. Action, Criticism, and Theory for Music Education 18 (1): 44-67. doi:10.22176/act18.1.44 
schools, high-demand schools and districts also search for the most cost-effective students-those who contribute to the educational efficiency of the school by testing well and requiring fewer resources. These policies provide incentives for administrators to create an image of their school that appeals to more privileged middle-class students and parents and discourages them from taking higher need students. This repositions administrators not as educational professionals charged with improving teaching and learning for all students, but as educational managers who must carefully craft a particular image to attract high-performing students and gather resources (Gewirtz 2002).

Market values that encourage competition between schools and particular notions of educational efficiency have had consequences for the material realities of teachers:

[The] increased competitiveness, target setting, and performance monitoring, and the narrowing of definitions of performance associated with the new managerialism can be seen to represent aspects of a qualitatively different regime of constraint and control in schools. (Gewirtz 2002, 72)

A narrow focus on academic performance, as measured by high-stakes testing and neoliberal notions of accountability, contributes to greater levels of surveillance of teachers, which has led to role intensification. Role intensification refers to the increased administrative duties teachers are expected to perform in relation to meeting learning benchmarks and quantifying student achievement. Role intensification increases the administrative nature of teaching by requiring educators to align their instruction to external standards, while constantly monitoring and quantifying student progress through formalized assessments (Valli and Buese 2007). Topdown neoliberal reforms diminish teacher control over curriculum and assessment and preoccupy teachers with the technocratic aspects of teaching (Gewirtz 2002) and contribute to a deskilling of teachers (Apple 2006).

The Core Arts Standards in music are highly technical documents that provide rubric-style standards for three artistic processes for each grade level and for four subject strands at the high school level. Aligning lesson plans to the appropriate standards and frequently assessing individual students creates an enormous amount of administrative work for music teachers, especially if one considers the large number of students whom elementary music teachers and large ensemble directors instruct. Moreover, predetermined learning outcomes restrict the possibilities for musicking (Small 1998) in the classroom and usurp the teachers'

Mullen, Jess. 2019. Music education for some: Music standards at the nexus of neoliberal reforms and neoconservative values. Action, Criticism, and Theory for Music Education 18 (1): 44-67. doi:10.22176/act18.1.44 
professional judgment. The National Core Arts Standards in Music contribute to the role intensification for music teachers by creating additional administrative work associated with aligning curricula to pre-determined benchmarks and constantly quantifying student progress. The encroachment of the administrative tasks on teachers' already-limited planning time creates conditions wherein teachers and administrators compensate by looking for outside resources to cope with an ever-growing list of responsibilities (Apple 2014). Role intensification, therefore, opens new markets for educational corporations, such as Quaver and Smart Music, to provide curriculum and assessment packages already aligned to the National Core Arts Standards in Music.

For neoliberals, pre-packaged curricula have two important effects toward their vision of public education. First, pre-packaged curricula suggest that teachers are not fit to make educational decisions for or with their students, contributing to the deskilling of these professionals. Rather, teachers become disposable laborinterchangeable workers that require little education or preparation to teach. Prepackaged curricula function as a cost-saving measure, as they enable experienced, highly qualified professionals to be replaced with inexperienced, short-term teachers who will work for less money. The second effect is that prepackaged curriculum and assessment packages form part of an agenda of hidden privatization of public schooling, in which public dollars earmarked for education increasingly find their way into private educational corporations (Ball and Youdell 2007). Under neoliberal reforms, schools are not only viewed as in service to the global economy, but also as untapped markets for profit.

\section{Opening New Markets}

Neoliberal reforms have reframed the means and ends of education according to free-market principles, resulting in a vision of schooling based on economic notions of efficiency and management. Not only have these reforms re-made public education in the image of corporate America, but public schooling itself is viewed as one of the last great untapped markets by venture capitalists. A 2014 article in The Nation highlights the earning potential venture capitalists see in public schooling.

Unlike in healthcare, energy and other areas of the economy that have moved from public to private hands, K-through-12 education has stubbornly remained largely out of the control of investors...That might be changing soon as barriers

Mullen, Jess. 2019. Music education for some: Music standards at the nexus of neoliberal reforms and neoconservative values. Action, Criticism, and Theory for Music Education 18 (1): 44-67. doi:10.22176/act18.1.44 
to investment are rapidly fading. As Eric Hippeau, a partner with Lerer Ventures, the venture capital firm behind viral entertainment company BuzzFeed and several education start-ups, has argued, despite the opposition of "unions, public school bureaucracies, and parents, the "education market is ripe for disruption." (Fang 2014)

The participation of the private sector in public education is part of an international trend ranging from "multibillion-dollar building projects and national contracts for systems management and testing to involvement in the small-scale, everyday activities of schools with teachers" (Ball and Youdell 2007, 23). Accountability regimes, coupled with the role intensification that teachers experience under neoliberal reforms, manufacture a need for data management systems, assessments, and standards-aligned curricula, which private companies are eager to provide.

The National Core Arts Standards in Music create new markets for products to cope with administrative tasks associated with the role intensification of teachers' work. Smart Music, a popular cloud-based software package, allows music teachers to create standards-aligned assignments and closely monitor student performance through standardized assessments. According to the Smart Music's Educator Blog:

Now more than ever, teachers need to document their effectiveness as educators by tracking student progress. Tracking the right student data can help demonstrate student achievement as well as proficiency of the teacher. These benchmarks are commonly referred to as Student Learning Objectives. Tracking SLO's helps to show that your students are meeting standards and demonstrate your impact as a teacher. (Streznewski 2018)

Smart Music recommends that users align their student learning objectives to the district, state, or national standards. The National Core Arts Standards in Music are an essential component for legitimizing assessment and data management systems provided by private companies, such as Smart Music.

The National Core Arts Standards represent a key component of neoliberal educational reforms in the arts. They connect music education to the production of human capital through the acquisition of 21st-century skills and provide a framework for constructing accountability regimes that encourage competition and efficiency. Moreover, the standards contribute to intensification of teachers' work, which in turn opens new markets for profit. While neoliberal ideology is arguably the strongest current in contemporary educational reforms, other ideological blocs on the right have an interest in educational standards as well.

Mullen, Jess. 2019. Music education for some: Music standards at the nexus of neoliberal reforms and neoconservative values. Action, Criticism, and Theory for Music Education 18 (1): 44-67. doi:10.22176/act18.1.44 


\section{Neoconservatives: Whose Standards?}

Whereas neoliberals prize free markets and look to a globalized future, neoconservatives look back to romanticized visions of the past and are largely concerned with preserving so-called traditional values in an increasingly multicultural world.

Neoconservatives are usually guided by a vision of the strong state. This is especially true surrounding issues of knowledge, values, and the body...based in a romantic appraisal of the past, a past in which "real knowledge" and morality reigned supreme, in which people "knew their place," and where stable communities guided by a natural order protected us from the ravages of society. (Apple 2006, 39)

In some ways, neoconservative ideologies conflict with neoliberalism, but the two groups have overlapping interests in educational standards. Whereas neoliberals rely on standards to improve educational efficiency through competitive markets, neoconservatives are deeply invested in the content of those standards.

For neoconservatives, the National Core Arts Standards in Music codify long held Eurocentric notions of musical value, thus preserving "real" musical knowledge in a time of increasing racial and cultural diversity. These standards, however, are not simply a mirror image of dominant culture groups, but rather a contested terrain. Dominant groups maintain hegemonic control by co-opting the viewpoints and language of marginalized groups. Economic, political, and cultural elites will seek a maximum amount of support from other groups for their educational policies "in return for conceding a minimum amount of diversification" (Apple 2014, 70). By incorporating marginalized voices, dominant groups respond to critiques while ceding as little power as possible. These allowances reflect the customer friendly market mentality of neoliberals, while ultimately retaining control over the standard's content-a primary concern for neoconservatives.

Throughout the National Core Arts Standards in Music, there are frequent references to a "varied repertoire of music" and even "diverse cultures, styles, and genres"-a clear nod to the inclusion of music from outside Western art music traditions; however, an examination of the Model Cornerstone Assessments (MCA's), a series of rubrics provided by NAfME to assess the students, reveals whose music counts. The MCA rubric for accomplished performance requires a student to:

Select a program of varied repertoire for performance including three contrasting musical works from ensemble music, formal solo or chamber ensemble, based on

Mullen, Jess. 2019. Music education for some: Music standards at the nexus of neoliberal reforms and neoconservative values. Action, Criticism, and Theory for Music Education 18 (1): 44-67. doi:10.22176/act18.1.44 
performer interest. Then analyze, prepare and perform all three works demonstrating an understanding of structural characteristics, proficiency of advanced technical and expressive skills, and comprehension of the appropriateness of the performance context (National Association for Music Education "Model Cornerstone Assessment" n.d., 3).

The use of the terms "ensemble music, formal solo or chamber ensemble" and the focus on the structural characteristics of the piece point to Eurocentric conceptions of music. Moreover, to meet the criteria for an accomplished performer, a student must include a piece from a graded repertoire list comprised almost exclusively of Western classical music. Regardless of National Core Arts Standards in Music use of the vaguely inclusive phrase "a varied repertoire of music," the values embedded in the MCAs codify already-dominant Eurocentric music practices and epistemologies.

Although the National Core Arts Standards in Music reimagine music education for a neoliberal world, much of their content remains recognizable. The three artistic processes, responding, performing, and creating music, are well-worn categories of musical interaction, and the MCAs rely on familiar concepts, including call-and-response activities, identifying musical elements, and employing compositional techniques such as theme and variations. The concepts embedded in the National Core Arts Standards in Music codify Eurocentric knowledge and practices in music education and represent a compromise between neoliberal and neoconservative interests.

\section{Resisting the Hegemonic Alliance: Possibilities of a Democratic Music Education}

The political logic of the National Core Arts Standards is understandable, if problematic. Music has historically held a marginalized position in public schools in the United States. On the surface, imitating educational reforms in mathematics and English language arts seems like a savvy strategy to elevate the status of music education in public schooling. Establishing educational standards has long been part of an effort to legitimize music as part of the core curriculum (Benedict 2006, Mark 1995); still, lessons from the 1994 National Standards in Music tell us otherwise, as music has yet to be elevated to the status of language arts and mathematics (Koza 2010). This well-intentioned advocacy effort is not only ineffective but adheres to ideologies that are in direct opposition to NAfME's mission "to advance

Mullen, Jess. 2019. Music education for some: Music standards at the nexus of neoliberal reforms and neoconservative values. Action, Criticism, and Theory for Music Education 18 (1): 44-67. doi:10.22176/act18.1.44 
music education by promoting the understanding and making of music by all" (National Association for Music Education, "Mission Statement," n.d., para. 2). Neoliberal policies that encourage competition and efficiency have largely failed to improve education for all students-especially the most marginalized. Rather, market-based policies have increased educational inequity by rewarding students and families with greater social, political, and economic capital and punishing those with less (Apple 2006, Gewirtz 2002). Additionally, the neoconservative values embedded in the National Core Arts Standards in Music codify Eurocentric epistemologies that limit the possibilities for a more expansive understanding of musicking (Small 1998) in classrooms.

The National Core Arts Standards in Music come at a time when music education is wrestling with its own equity issues. Although music courses are widely available in public schools (Abril and Gault 2008), the quality of music education programs correlate to students' socioeconomic status (Parsad and Spiegelman 2012), and participation rates vary by race, gender, class, and geography (Elpus and Abril 2011). Aligning music education with neoliberal ideologies and codifying Eurocentric musical values through the National Core Arts Standards in Music only stands to exacerbate existing inequities. Rather than adapting music education to contemporary reforms, music educators are uniquely positioned to resist these policies by joining a growing movement of students, parents, scholars, and activists who oppose the corporatization of education.

Analyzing how certain ideological blocs shape the identity of music education becomes a key component in resisting the new common sense of school reform (Apple 2006). Equally important is engaging in counter-hegemonic practices that reject neoliberal notions of standardization, meritocracy, and narrow measures of accountability (Apple and Beane 2007). Democratic modes of music education hold promise and challenges for countering hegemonic alliances.

Music educators in the United States have rhetorically supported the concept of democracy and have made claims regarding music's ability to contribute to a democratic society, if only indirectly.

Thus far, however, few music educators have deigned to describe and explain what they mean by democracy and democratic citizenship, that is, beyond everyday "common sense" notions of freedom and equality of opportunity...and the belief that school programs should be more musically diverse and inclusive. The concept of democracy as it applies to music education remains under-defined and taken for granted as a self-evident truth. (Woodford 2016, 51)

Mullen, Jess. 2019. Music education for some: Music standards at the nexus of neoliberal reforms and neoconservative values. Action, Criticism, and Theory for Music Education 18 (1): 44-67. doi:10.22176/act18.1.44 
Reliance on common sense notions of democracy becomes problematic in an era of neoliberal reform. Under neoliberal ideology, democracy has been reconstructed as consumer choice:

For neoliberals, the world, in essence, is a vast supermarket. Consumer choice is the guarantor of democracy. In effect, education is seen as simply one more product like bread, cars, and television. (Apple 2006, 32)

This "thin" version of democracy stands in contrast to a "thick" notion of democracy in which citizens, students, parents, teachers, and community members actively participate in the managing of institutions (Apple 2006). A thick vision of democracy is guided by a concern for the welfare of others, the open flow of ideas, and critical reflection to evaluate ideas, problems, and policies (Apple and Beane 2007).

Music education advocacy in the United States has long employed a thin notion of democracy-attempting to convince students, parents, and administrators to buy what music education is selling, whether it is improved test scores or 21st-century skills. Rather than continuing to market music education to the public, the field might better serve students and communities by engaging in a thick notion of democracy in which students, parents, colleagues, and community members are legitimate participants in creating a culturally relevant and affirming music education-not simply potential customers.

Given that the term democracy itself is contested terrain with a variety of interpretations (Apple 2006, Habermas 1994, Woodford 2016), it is essential to provide a specific vision for a democratic music education. This vision, however, is deeply local; it is not a prescription or an endpoint, but rather a process or way of being in the world. Biesta (2013) describes this process-based orientation as the weak way of education in juxtaposition to a "strong, secure, predictable, and riskfree" (3) education:

The educational concern rather lies in the transformation of what is desired into what is desirable. It lies in the transformation of what of is de facto desired into what can justifiably be desired-a transformation that can never be driven from the perspective of the self and its desires, but always requires engagement with what or who is other. It is, therefore, again, a dialogical process. This makes the educational way the slow way, the difficult way, the frustrating way, and so we might say, the weak way, as the outcome of this process can neither be guaranteed nor secured. (Biesta 2013, 3 italics original)

Mullen, Jess. 2019. Music education for some: Music standards at the nexus of neoliberal reforms and neoconservative values. Action, Criticism, and Theory for Music Education 18 (1): 44-67. doi:10.22176/act18.1.44 
This shift from a safe outcome-based education to a risky education-where what is desired must always be justified and remade through a dialogical process-resists neoliberal notions of education that assume educational standards are justifiable. Biesta's understanding of the weak way of education requires teachers and students alike to engage in a dialogical process with each other, creating a collaborative and inherently social mode of music education (Allsup 2003).

At the center of this view of a democratic music education is a reciprocal dialogue between students and teachers. Paulo Freire (1970) acknowledged the transformational potential of dialogue:

Through dialogue, the teacher-of-the-students and the students-of-the-teacher cease to exist and a new term emerges: teacher-student and student-teachers. The teacher is no longer merely the-one-who-teaches, but one who is himself [sic] taught in dialogue with the students, who in turn while being taught also teaches. They become jointly responsible for a process in which all grow. (80)

Freire describes the dual roles of both teacher-student and student-teacher that is central to democratic modes of music education. Through this process, teacherstudents and student-teachers enter into the educational endeavor together, sharing their own musical knowledge, creating possibilities for transformation.

A democratic music education that centers a dialogical process is inherently messy and imperfect. Teachers and students alike enter the classroom in different positions of power and agency to participate in the dialogical process. In our current reality, dialogical relationships between students and teachers cannot totally erase teacher-student hierarchies; however, dialogue opens possibilities to mitigate power differentials and allows students to have a greater voice, agency, and ownership in the classroom community. Moreover, teachers must consider how students who are marginalized based on their race, class, gender, ability or other axes of difference might be silenced or excluded in classroom dialogue. Considering students' individual and collective positionalities requires teachers to subscribe to a positive view of rights (see Habermas 1994) within the classroom, whereby all students are provided the opportunities and means to enter the dialogical process and participate in classroom life. This view of a democratic music education requires a continual making and remaking of the music classroom towards greater equity for all students, with the understanding that equity is not an arrival point, but rather an unobtainable ideal to continually strive toward.

Mullen, Jess. 2019. Music education for some: Music standards at the nexus of neoliberal reforms and neoconservative values. Action, Criticism, and Theory for Music Education 18 (1): 44-67. doi:10.22176/act18.1.44 
This vision of a democratic music education provides possibilities for transformation and resistance to neoliberal and neoconservative reforms. By engaging in a dialogical process with teachers, students disrupt the hidden curriculum of neoliberal reforms that define teaching as the transfer of knowledge and skills, and learning as meeting prescribed benchmarks, as demonstrated by narrow measures of accountability.

The idea that students learn from the practices in which they take part is also helpful for understanding why the hidden curriculum is so effective-and often far more effective than the official curriculum. The hidden curriculum is, after all, located in the very practices in which children and students take part during their time in school, while the official curriculum is a much more artificial add-on to the real "life in schools." (Biesta 2013, 32)

Democratic modes of music education offer an alternative hidden curriculum that reclaim learning as a collaborative and dialogical process, driven by concerns beyond the individual. This transforms the relationship between the student and the institution of schooling. Instead of being conceptualized as a commodity, schools are reclaimed as places for active engagement and exploration.

Another possibility for transformation lies in the students' identity and relationship to their own musical world. Through a dialogical process, students reframe themselves as active participants in their own education rather than customers preparing themselves for the global economy. In the context of a music class, the dialogical process between teachers and students yields the production of locally and culturally specific musical experiences and artifacts grounded in youth culture. This shifts student identities from cultural consumers to cultural producers, with a focus on student agency or "the manner in which young people adapt, feel ownership, and transform the cultural knowledge they construct and create both in and out of school" (Allsup, Westerlund and Shieh 2018, 442). This view of music education runs counter to neoliberal ideology, in which so-called experts create standards of legitimate knowledge that educators are expected to teach. By employing democratic principles that center youth agency and a dialogical exchange between all classroom participants, music educators could more authentically engage their students and the communities they serve. Rather than adopting and further legitimizing neoliberal discourses and neoconservative values that serve to exclude, NAfME and other highly visible music education advocacy groups might better serve the field by promoting counter-hegemonic forms of music education that resist the new common sense of school reform.

Mullen, Jess. 2019. Music education for some: Music standards at the nexus of neoliberal reforms and neoconservative values. Action, Criticism, and Theory for Music Education 18 (1): 44-67. doi:10.22176/act18.1.44 


\section{But Where is the Pedagogy?}

I recently presented this article as a conference paper at the May Day Group Colloquium 30. During the question and answer portion of my presentation, an audience member asked a thoughtful and poignant question in response to my suggestion for a democratic music education, asking "but where is the pedagogy?" A democratic music education will, by its very nature, look different in different settings. Because of the deeply local nature of a democratic music education, no single pedagogy or method will be appropriate. Instead, educators may need to borrow from multiple pedagogies, including those that are indigenous to the communities they serve (see Emdin 2016). This negotiation is part of the democratic enterprise, wherein students and teachers enter into a dialogical process. This vision of music education engages with students, parents, and community in a collaborative manner that is antithetical to neoliberal ideals. Participation goes beyond simply singing or playing in an ensemble or choosing repertoire.

To provide an example of what this kind of music education might look like, I return to my own experiences as a high school music teacher in a large Midwestern city. As previously mentioned, I experienced many of the surveillance and accountability measures enacted under neoliberal reforms. However, because my band class was an elective and was less scrutinized than my general music classes, I was able to create a classroom that embodied the kind of democratic music education described above. Many of my students had little or no experience with wind instruments, but there was a strong community drumline tradition in their neighborhood. In our band class, I shared my knowledge of wind instruments as students shared their knowledge of local drumline traditions and the popular music from their own lives. Since much of the available repertoire for beginning band was (and most likely still is) of little interest to high school students, we collectively composed our own music. At times this was stitching together exercises from traditional method books and creating interesting arrangements with complex drumline style accompaniments. At other times, students suggested songs from their own lives, and we transcribed and arranged them together. Students learned traditional notation, but they also relied on their own forms of notation to document arrangements or transcribed music and played by ear. The music that we created and performed was unique to our particular classroom and represented a dialogical relationship between students and teacher. We all shared our own expertise,

Mullen, Jess. 2019. Music education for some: Music standards at the nexus of neoliberal reforms and neoconservative values. Action, Criticism, and Theory for Music Education 18 (1): 44-67. doi:10.22176/act18.1.44 
cultural knowledge, and resources to produce something new and meaningful for all participants involved.

When I initially wrote this essay, I hesitated to share my own adventures in democratic musicking (Small 1998), as examples are too often taken as templates. Also, I do not want to suggest that our classroom was perfectly democratic at all times; it was instead a messy and flawed process of negotiation and renegotiation at a particular location, space, and time. If I were to go back and do it again, it would no doubt turn out differently. Part of our work as music educators is to think critically about what a democratic music education might look like for and with our own students. We must consider a music education beyond learning objectives and what we think they should know. Rather, we should ask: how can teachers, students, and communities work together dialogically to provide a meaningful and engaging music education for all participants?

\section{About the Author}

Jess Mullen is a doctoral candidate in music education at the University of Wisconsin-Madison, where he teaches courses on popular music pedagogy and supervises student teachers and practicum students. Prior to graduate school, Mr. Mullen taught high school general music and band in Chicago Public Schools. Mr. Mullen has presented research posters and papers at national and international conferences addressing a variety of equity related topics that include racial inequity in music education, the effects of neoliberal educational policies, and popular music pedagogy in teacher education. His research interests include music teacher education, equity in music education, critical race theory, and education policy.

\section{References}

Abril, Carlos R., and Brent Gault. 2008. The state of music in secondary schools: The principal's perspective. Journal of Research in Music Education 56 (1): 68-81.

Allsup, Randall Everett. 2003. Mutual learning and democratic action in instrumental music education. Journal of Research in Music Education 51 (1): 2437 .

Allsup, Randall Everett, Heidi Westerlund, and Eric Shieh. 2018. Youth culture and secondary education. In Music learning and teaching in infancy, childhood, and adolescence, edited by Gary E. McPherson and Graham F. Welch, 438-61. New York: Oxford University Press.

Mullen, Jess. 2019. Music education for some: Music standards at the nexus of neoliberal reforms and neoconservative values. Action, Criticism, and Theory for Music Education 18 (1): 44-67.

doi:10.22176/act18.1.44 
Apple, Michael W. 2006. Educating the "right" way: Markets, standards, god, and inequality. New York, NY: Routledge.

Apple, Michael W. 2014. Official knowledge: Democratic education in a conservative age. New York, NY: Routledge.

Apple, Michael W., and James Beane. 2007. Democratic schools: Lessons in powerful education, 2nd ed. Portsmouth, NH: Heinemann.

Ball, Stephen J. 2003. The teacher's soul and the terrors of performativity. Journal of Education Policy 18 (2): 215-28.

Ball, Stephen J. 2012. Global Education Inc.: New policy networks and the neoliberal imaginary. New York, NY: Routledge.

Ball, Stephen J., and Deborah Youdell. 2007. Hidden privatisation in public education. In Education International 5th World Congress, London, July 2007. London: Institute of Education, University of London.

Benedict, Cathy. 2006. Chasing legitimacy: The US national music standards viewed through a critical theorist framework. Music Education Research 8 (1): $3-16$.

Biesta, Gert J. J. 2013. The beautiful risk of education. Boulder, CO: Paradigm Publishers.

Common Core State Standards Initiative. n.d. Development process. Accessed August 31, 2018. http://www.corestandards.org/about-the-standards/development-process/

Elpus, Kenneth, and Carlos, Abril. 2011. High school music ensemble students in the United States: A demographic profile. Journal of Research in Music Education 59 (2): 128-45.

Emdin, Christopher. 2016. For white folks who teach in the hood ... and the rest of y'all too: Reality pedagogy and urban education. Boston: Beacon Press.

Fang, Lee. 2014. Venture capitalists are poised to "disrupt" everything about the education market. The Nation September 25, 2014. https://www.thenation.com/article/venture-capitalists-are-poised-disrupt-everything-about-education-market/

Freire, Paulo. 1970. The pedagogy of the oppressed. New York: Continuum.

Mullen, Jess. 2019. Music education for some: Music standards at the nexus of neoliberal reforms and neoconservative values. Action, Criticism, and Theory for Music Education 18 (1): 44-67. doi:10.22176/act18.1.44 
Gewirtz, Sharon. 2002. The managerial school: Post-welfarism and social justice in education. New York, NY: Routledge.

Habermas, Jurgen. 1994. Three normative models of democracy. Constellations 1 (1): $1-10$.

Horsley, Stephanie. 2009. The politics of public accountability: Implications for centralized music education policy development and implementation. Arts Education Policy Review 110 (4): 6-13. doi: 10.3200/AEPR.110.4.6-13

Horsley, Stephanie. 2015. Facing the music: Pursuing social justice through music education in a neoliberal world. In The Oxford handbook of social justice in music education, edited by Cathy Benedict, Patrick Schmidt, Gary Spruce, and Paul Woodford, 63-77. New York: Oxford University Press.

Hursh, David. 2007. Assessing No Child Left Behind and the rise of neoliberal education policies. American Educational Research Journal 44 (3): 493-518. doi: 10.3102/0002831207306764

Koza, Julia, Eklund. 2010. When policy disappoints: Still worth less after all these years. Bulletin of the Council for Research in Music Education 189 (Winter): 77-95.

Mark, Michael L. 1995. Music education and the national standards: A historical review. The Quarterly Journal of Music Teaching and Learning 6 (2): 34-43.

Mark, Michael L. 2002. A history of music education advocacy. Music Educators Journal 89 (1): 44-8. https://doi.org/10.2307/3399884

National Association for Music Education. n.d. Mission statement. Accessed on August 31, 2018 https://nafme.org/about/mission-and-goals/mission-statement/

National Association for Music Education. n.d. Model cornerstone assessment. Accessed on August 31st, 2018. https://nafme.org/wp-content/files/2014/11/Ensemble_Performing_Accomplished_Advanced_MCA.pdf

National Coalition for Core Arts Standards. 2016. National core arts standards: A conceptual framework for arts learning. Accessed August 31, 2018. https://www.nationalartsstandards.org/sites/default/files/Conceptual\%20Framework\%2007-21-16.pdf

Mullen, Jess. 2019. Music education for some: Music standards at the nexus of neoliberal reforms and neoconservative values. Action, Criticism, and Theory for Music Education 18 (1): 44-67.

doi:10.22176/act18.1.44 
Parsad, Basmat, and Maura Spiegelman. 2012. Arts education in public elementary and secondary schools 1999-200O and 2009-10. NCES No. 2012-014 Washington D.C.: National Center for Education Statistics, Institute of Education Sciences, U.S. Department of Education.

Partnership for 21st Century Learning. n.d. Our history. Accessed on August 31, 2018. http://www.p21.org/about-us/our-history

Partnership for 21st Century Learning. 2015. P21 framework and definitions. Accessed on August 31, 2018. http://www.p21.org/storage/documents/ docs/P21_Framework_Definitions_New_Logo_2015.pdf.

Rotherham, Andrew. J., and Daniel Willingham. 2009. 21st century skills: The challenges ahead. Educational Leadership 67 (1): 16-21.

Shuler, Scott. C, Martin Norgaard, and Michael Blakeslee. 2014. The new national standards for music educators. Music Educators Journal 101 (1): 41-9. https://doi.org/10.1177/0027432114540120

Small, Christopher. 1998. Musicking: The meanings of performing and listening. Middletown, CT: Wesleyan University Press.

Streznewski, Cynthia. 2018. Tracking student learning objectives in music. May 22, 2018. The Music Educator Blog (blog). https://www.smartmusic.com/blog/ tracking-student-learning-objectives-in-music/

U.S. Department of Education. n.d. Race to the top fund. Accessed on August 31, 2018. https://www2.ed.gov/programs/racetothetop/index.html

Valli, Linda, and Daria Buese. 2007. The changing roles of teachers in an era of high-stakes accountability. American Educational Research Journal 44 (3): 519-58.

Woodford, Paul. 2016. Confronting innocence: Democracy, music education, and the neoliberal 'manipulated man'. In Giving voice to democracy in music education: diversity and social justice, edited by Lisa C. Delorenzo, 51-64. New York: Routledge.

\section{Notes}

${ }^{1}$ In true neoliberal fashion, during the time between researching and writing this article and its publication, the Partnership for 21st Century Learning has been acquired by Battelle for Kids-a national educational not-for-profit organization. As such, all of the websites listed as references for the Partnership for 21st Century

Mullen, Jess. 2019. Music education for some: Music standards at the nexus of neoliberal reforms and neoconservative values. Action, Criticism, and Theory for Music Education 18 (1): 44-67. doi:10.22176/act18.1.44 
Learning redirect to the Battelle for Kids website. Readers can access the original websites that I reference by searching the original web address using the Internet Archive at https://archive.org/web/. I recognize there is a danger in relying upon web-based sources and data and, ironically, this is the result of the very forces I am critiquing.

${ }^{2}$ Available at http://www.p21.org/storage/documents/P21_arts_map_final.pdf 